\title{
Investigation of the effect of supramaximal eccentric contractions on muscle damage and recovery between the dominant and non-dominant arm
}

\author{
Yapıcı A. ${ }^{1 \mathrm{ABCDE}}$, Yalçın H.B. ${ }^{2 \mathrm{ABCD}}$ \\ ${ }^{1}$ School of Physical Education and Sports, Hatay Mustafa Kemal University, Turkey \\ ${ }^{2}$ Faculty of Physical Education and Sports, Bolu Abant Izzet Baysal University, Turkey
}

Authors' Contribution: A - Study design; B - Data collection; C - Statistical analysis; D - Manuscript Preparation; E - Funds Collection.

\begin{abstract}
Purpose:

This research aimed to examine the effects of supramaximal eccentric contractions on the damage of muscle and recovery between the dominant and non-dominant arm. The study was participated by ten male volunteer students who do not have any musculoskeletal and metabolic compliant. This research designed as a cross-over type research.

Material: $\quad$ Venous blood samples were drawn before the bout, immediately after the bout one min., moreover, at the $6^{\text {th }}, 24^{\text {th }}, 48^{\text {th }}$, and 72 nd hours after training. Data were analyzed using the SPSS 21.0 statistical software package. After exercise, the non-parametric Wilcoxon Signed Ranks Test was used to decide the dominant and non-dominant arm influence. Statistical significance for all analyses was accepted at $p<$ 0,05 .

Results: $\quad$ There was a significant statistical difference in the right, and left arm Creatine Kinase (CK) values at the time when exercise start, $48^{\text {th }}$ and 72 nd hours $(p<0,05)$. There was no statistically significant difference in right and left arm Lactate Dehydrogenase values after exercise $(p>0,05)$.

Conclusions: $\quad$ There was an increase in muscle damage at $24^{\text {th }}$ and $48^{\text {th }}$ hours after supramaximal eccentric exercise, and it was turned back the start level at 72 nd hours. While the arm which is non-dominant recovery is faster than the dominant arm.

Keywords: $\quad$ eccentric contraction, recovery, muscle damage, creatine kinase, lactate dehydrogenase.
\end{abstract}

\section{Introduction}

According to Hollmann [1], muscle strength that is confronted with resistance may contract or withstand a specific endurance and according to Nett [2], the ability of a muscle to resist a resistance by tension and relaxation. There are many different methods in order to improve muscle strength. That feature is improved with changing both training methods and contraction types [3]. Soft tissue injuries due to sprains and bumps are common. Those injuries can be treated with rehabilitation implications. In addition to the soft tissue injuries, cellular damage also occurs during the exercise. This situation mainly described as microtrauma or microinjury or muscle damage $[4,5]$. Intensity and form of the exercise cause different levels of muscle damage [6].

Skeletal muscle damage occurs after a high-intensity or unusual type of exercise, and this type of muscle damage is a widespread physiological condition and can occur even in the activities needed in our daily life. Three types of muscle damage symptoms are known in long-term exercises, ongoing or intermittent forced contractions. The most common of these is known as delayed-onset muscle soreness (DOMS), and as a result, people complain of weakness, fatigue and tenderness in the muscle that starts 12-48 hours after exercise [7, 8].

Increased blood levels of some muscle enzymes involved in circulation as a result of deterioration of muscle membrane are biochemical symptoms indicating

\footnotetext{
(c) Yapıcı A., Yalçın H.B., 2019

doi:10.15561/18189172.2019.0605
}

muscle damage and degree. The intracellular localization of enzymes is essential in determining the degree of cell damage. The enzyme that only shows activity in a particular tissue or has much higher activity in a particular tissue is called the dominant enzyme. Increased serum activity of such an enzyme indicates damaged tissue. Determination of the total amount of damage caused in the muscle is challenging since the exercise response is at different levels in different muscle and muscle fibers, the different muscles contain enzyme and protein markers at different concentrations, and the damage is not homogeneously distributed in the muscle $[9,10]$.

Increased levels of some enzymes cause severe muscle tissue damage in large muscle tears. Skeletal muscle damage causes muscle-specific components to leak from the membrane into the bloodstream. Structures used in studies to detect skeletal and cardiac muscle damage; usually examine creatine kinase (CK) and its lower isoforms, myoglobin, aspartate aminotransferase (AST), lactate dehydrogenase $(\mathrm{LDH})$, brain natriuretic peptide (BNP), atrial natriuretic peptide (ANP), carbonic anhydrase, troponin, and muscle-building proteins [11, 12]. The most important and most used of these structures is CK $[13,14]$.

CK is an enzyme found in high density in the heart, skeletal muscle, and brain tissue. CK in the brain content rarely crosses the blood-brain barrier and circulates. There are three isoenzymes called MM, MB, BB. MM (CK3) found in skeletal and heart muscle, BB (CK1) in the brain, $\mathrm{MB}(\mathrm{CK} 2)$ in the heart muscle. The source 
of CK levels measured in circulation is predominantly skeletal or cardiac muscle. Skeletal or cardiac muscle trauma or necrosis increases the circulatory level of this enzyme [15]. Therefore, at high CK levels, skeletal, or cardiac muscle damage should be sought first $[16,17]$. According to Kaplan and Pesce [17], average CK values are between 95-140 U / L. CK's upper reference values are twice as high in athletes as in non-athletes. Schumann and Klauke [18], set these limits at 391-398 U / L for men; In women, between 240-207 U / L.

LDH is an enzyme that is found in many tissues and passes into serum if these tissues are damaged. The determination of isoenzymes can demonstrate the tissue from which LDH originates. When operated at $37^{\circ} \mathrm{C}$, normal values are 210-420 U / L [19, 20].

LDH shock and circulatory failure, hypoxia, heart failure, excessive hyperthermia, acute myocardial infarction, cholestasis, primary tumors of the liver, megaloblastic and pernicious anemia, hemolytic anemia, lung diseases, increases in cases of muscle diseases. Increases in skeletal muscle trauma, inflammatory or degenerative muscle diseases. There are five isoenzymes in the circulation, called LDH-1, 2, 3, 4 and 5. Total LDH activity increases in many tissue and organ diseases due to the widespread tissue distribution of isoenzymes. Therefore, an additional examination is required for differential diagnosis [20, 21].

Muscle damage caused by eccentric exercise can be assessed by direct methods such as muscle biopsy or magnetic imaging, or indirectly by markers such as decreased muscle strength, edema, pain, increased serum levels of muscle enzymes and some markers of inflammation. Direct methods are often not preferred due to several difficulties in practice, but it is seen that changes in muscle strength and serum enzymes are mostly used in the assessment of eccentric muscle damage [22, 23].

Clarkson et al. [24], showed that very intensive eccentric exercise leads to an adaptation that causes less damage when repeated in the same way after a few weeks. It is not known precisely when and how this adaptation occurred. However, it was found that a person who repeated an exercise within five days showed an adaptation response. After five days of exercise, people experienced mild pain despite improvement and reduced loss of strength and range of motion. Thus, although the muscle is not fully restored, a specific adaptation has occurred [25].

In their study, Nosaka et al. [26] made the same highintensity exercise twice in the two groups, the first group did the exercises every six weeks, and the other group performed ten weeks apart. As a result, they found that isometric strength loss, arm flexion at full flexion and muscle pain were significantly lower in the group who exercised at six weeks interval compared to the first application in the second application. In the exercise group after ten weeks, it was found that there were significantly lower answers in the rest arm angle compared to the first in the second application. However, there were similarities between the first and second applications in terms of muscle pain level, arm angle at full flexion, and isometric strength loss.

In terms of CK, there was almost no increase in both groups after the second application. When a small sample of these subjects performed exercise after six months, CK response was still low, and all other measurements were close to the values at the first application. Accordingly, adaptation, strength recovery, muscle shortening state (closed-arm angle) and muscle pain for six weeks, sudden muscle contraction (open arm angle) takes about ten weeks and six months for CK response [24].

After the eccentric exercise, a certain period is required to return the markers of damage to the muscle [27]. Clancy and Clarkson [28], suggest that 3-day immobilization after damage-induced eccentric exercise improves isometric force recovery but has no effect on other muscle functions. Lehto et al. [29], muscle regeneration was accelerated by 5 -day immobilization and return to regular movements after the damage caused in the muscle.

\section{Materials and Methods}

\section{Participants}

This research has aimed the examine the effects of supramaximal eccentric contractions on the damage of muscle and recovery between dominant and non-dominant arm. The study consists of 13 male volunteers active in sports. It was determined that three subjects exercised outside the practice while the study was in progress, and they were excluded from the study. The research was carried out based on the cross-tab test model. Before work begins, an ethical report was taken from Abant Izzet Baysal University Clinical Research Ethics Committee.

Table 1. Demographic characteristics of the research group.

\begin{tabular}{llllll}
\hline Variables & $\mathbf{N}$ & Minimum & Maximum & $\overline{\mathbf{x}}$ & S.D. \\
\hline Age & 10 & 22 & 26 & 23,3 & 1,3 \\
Height & 10 & 170 & 192 & 178,9 & 7,09 \\
Weight & 10 & 60 & 100 & 78,2 & 13,8 \\
\hline
\end{tabular}

According to Table 1, the mean age of the study was $23.3 \pm 1.3$ years, the mean height was $178.9 \pm 7.09 \mathrm{~cm}$, and the mean body weight was $78.2 \pm 13.8 \mathrm{~kg}$, who do not have any musculoskeletal and metabolic compliant ten male volunteer students participated. It was determined by asking themselves whether they use any ergogenic adjuvant and regular medication for health problems and their dominant arms. All subjects indicated that they used dominant right arms.

An information meeting was held with the students who wanted to participate in the research, and the subjects were informed about the study by giving pre-experiment information form and test protocol. The subjects were asked to read and sign the form indicating that they were volunteer, and their body weights were carried out in standard clothing (shorts and t-shirts), without shoes, electronic scales in the upright position, height 
measurements were made with height meter and biceps circumference measurements for both arms with a tape measure. Then the groups were determined by a random method.

The exercise protocol was held between 16:00-17:00. One week before the study, the maximal weights of the subjects were determined by one-rep maximum (1 RM) method. In order to eliminate the differences that may arise from experience, cross-tab pattern was applied. One group performed the exercise with the dominant arm and the other group with the non-dominant arm. Then the groups changed places.

Exercise Protocol

Before starting the study, venous blood samples of the subjects were taken from the antecubital vein in a resting and sitting manner by the health personnel. Five of the subjects then performed the eccentric phase of the biceps lifting movement with their supramaximal weights with the right arm and the other five with their left arms. The subjects had a passive role in the concentric phase, and the person conducting the study performed that phase. The study was continued until the person was unable to continue the exercise, and the subject was completed by disrupting the rhythm or voluntarily terminating the study. The health personnel took venous blood samples at the first minute, 6th, 24th, 48th, and 72nd hours following the end of the study. Six days after the blood was drawn at $72 \mathrm{~h}$, subjects performed the study with their other arms, and the blood collection procedure was re-administered as in the first stage.

Statistical Analysis

The data obtained from the study were analyzed in SPSS 21.0 package program. The Wilcoxon Signed Ranks Test was used to determine the interaction of Creatine Kinase (CK) and Lactate Dehydrogenase (LDH) in the dominant and non-dominant arms at the first minute, 6 , 24, 48 and 72 hours after exercise. Bonferroni correction was used to show a statistical difference. The results were evaluated at $\mathrm{p}<0.05$ significance level.

\section{Results}

According to Table 2, the mean training age of the group was $9.6 \pm 2$ years, the average training frequency was $3.6 \pm 0.6$ days, the average total training time was 6.7 \pm 2.1 hours, the $\mathrm{D}$ arm maximal force average $20.5 \pm 4.6$ $\mathrm{kg}$, the ND arm maximal strength $20.2 \pm 4.7 \mathrm{~kg}$ detected it was.

In Table 3, D and ND arm CK enzyme values of the first minute, 6, 24, 48 and 72nd hours following the exercise were analyzed comparatively and the first minute, 6, 24 and 72nd hours were statistically analyzed. There was no significant difference ( $p>0.05)$. A statistically significant difference was found in the 48th-hour values after exercise (Z: $-2.191 ; \mathrm{p}<0.05)$.

According to Table 4, There was no significant difference the pre-exercise (resting) value was compared with the $\mathrm{D}$ arm CK enzyme activities at the first minute, 6 and 72 nd hours $(p>0.05)$. A statistically significant difference was found in the 24 and 48th hours values ( $p$ $<0.05)$.

According to Table 5, pre-exercise (resting) values were analyzed by comparing the CK enzyme activities of the ND arm at the first minute, 6, 24, 48, and 72nd hours after the exercise. There was no statistically significant difference at the first minute, 48 and 72 nd hours values $(p>0.05)$. A statistically significant difference was found in the 6 and 24th hours values $(\mathrm{p}<0.05)$.

Table 6, 6, 24, 48 and 72nd hours after exercise D and ND arm LDH enzyme values were analyzed; comparatively, LDH enzyme recovery phase comparison

Table 2. Physiological characteristics of the research group (D:Dominant-ND: Non-Dominant)

\begin{tabular}{|c|c|c|c|c|c|}
\hline Variables & $\mathbf{N}$ & Minimum & Maximum & $\overline{\mathbf{x}}$ & S.D. \\
\hline Training age & 10 & 6 & 12 & 9,6 & 2,0 \\
\hline Training frequency & 10 & 3 & 5 & 3,6 & 0,6 \\
\hline Total training time & 10 & 3 & 10 & 6,7 & 2,1 \\
\hline D max. force & 10 & 12,5 & 30 & 20,5 & 4,6 \\
\hline ND max. force & 10 & 12,5 & 30 & 20,2 & 4,7 \\
\hline
\end{tabular}

Table 3. Compared to the D and ND CK enzyme statistical analysis values

\begin{tabular}{llllll}
\hline \multirow{2}{*}{ Variables } & CkND 0. $\mathbf{m}-$ & CkND 6. $\mathbf{h}-$ & CkND 24. $\mathbf{h}-$ CkD & CkND 48. $\mathbf{h}-$ CkD & CkND 72. $\mathbf{h}-$ CkD \\
& CkD 0. $\mathbf{m}$ & CkD 6. $\mathbf{h}$ & $\mathbf{2 4 .} \mathbf{h}$ & $\mathbf{4 8} . \mathbf{h}$ & $\mathbf{7 2 .} \mathbf{h}$ \\
\hline Z & $-0,561$ & $-1,172$ & $-1,478$ & $-2,191$ & $-1,581$ \\
Significance & 0,575 & 0,241 & 0,139 & 0,028 & 0,114 \\
\hline
\end{tabular}

Table 4. Resting and D compared CK enzyme statistical analysis values

\begin{tabular}{|c|c|c|c|c|c|c|c|c|c|c|}
\hline Variables & $\begin{array}{l}\text { Ck rest - } \\
\text { D } 0 . \mathrm{m}\end{array}$ & $\mathbf{C k}$ & $\begin{array}{l}\text { Ck rest - } \\
\text { D } 6 . h\end{array}$ & $\mathbf{C k}$ & $\begin{array}{l}\text { Ck rest - } \\
\text { D 24. h }\end{array}$ & $\mathbf{C k}$ & $\begin{array}{l}\text { Ck rest - } \\
48 . h\end{array}$ & CkD & $\begin{array}{l}\text { Ck rest - } \\
\text { D 72. h }\end{array}$ & $\mathbf{C k}$ \\
\hline Z & $-0,969$ & & $-1,172$ & & $-1,836$ & & $-1,784$ & & $-1,275$ & \\
\hline Significance & 0,333 & & 0,241 & & 0,014 & & 0,041 & & 0,202 & \\
\hline
\end{tabular}


Table 5. Resting and ND compared CK enzyme statistical analysis values

\begin{tabular}{|c|c|c|c|c|c|c|c|c|c|c|}
\hline Variables & $\begin{array}{l}\text { Ck rest - } \\
\text { ND } 0 . \mathrm{m}\end{array}$ & Ck & $\begin{array}{l}\text { Ck rest - } \\
\text { ND } 6 . h\end{array}$ & Ck & $\begin{array}{l}\text { Ck rest - } \\
\text { ND 24. h }\end{array}$ & Ck & $\begin{array}{l}\text { Ck rest - } \\
\text { ND 48. } h\end{array}$ & Ck & $\begin{array}{l}\text { Ck rest - } \\
\text { ND 72. h }\end{array}$ & Ck \\
\hline Z & $-1,784$ & & $-2,293$ & & $-1,988$ & & $-1,886$ & & $-1,478$ & \\
\hline Significance & 0,074 & & 0,022 & & 0,047 & & 0,059 & & 0,139 & \\
\hline
\end{tabular}

Table 6. D and ND compared LDH enzyme statistical analysis values

\begin{tabular}{llllll}
\hline \multirow{2}{*}{ Variables } & $\begin{array}{l}\text { Ldh ND 0. } \mathbf{~}- \\
\text { Ldh D 0. } \mathbf{~ m}\end{array}$ & $\begin{array}{l}\text { Ldh ND 6. } \mathbf{~}- \\
\text { Ldh D 6. } \mathbf{~}\end{array}$ & $\begin{array}{l}\text { Ldh ND 24. } \mathbf{~ - ~ L d h ~} \\
\text { D 24. } \mathbf{~ h}\end{array}$ & $\begin{array}{l}\text { Ldh ND 48. } \mathbf{~ - ~ L d h ~} \\
\text { D 48. } \mathbf{~}\end{array}$ & $\begin{array}{l}\text { Ldh ND 72. } \mathbf{~}-\text { Ldh } \\
\text { D 72. } \mathbf{~}\end{array}$ \\
\hline Z & $-1,482$ & $-1,008$ & $-0,765$ & $-0,510$ & $-0,510$ \\
Significance & 0,138 & 0,314 & 0,444 & 0,610 & 0,610 \\
\hline
\end{tabular}

Table 7. Resting and D compared LDH enzyme statistical analysis values

\begin{tabular}{|c|c|c|c|c|c|c|c|}
\hline Variables & $\begin{array}{l}\text { Ldh rest - } \\
\text { Ldh D 0. m }\end{array}$ & $\begin{array}{l}\text { Ldh rest - } \\
\text { Ldh D 6. h }\end{array}$ & $\begin{array}{l}\text { Ldh rest - } \\
\text { Ldh D 24. h }\end{array}$ & $\begin{array}{l}\text { Ldh rest - } \\
\text { D } 48 . h\end{array}$ & Ldh & $\begin{array}{l}\text { Ldh rest - } \\
\text { D 72. } h\end{array}$ & Ldh \\
\hline$Z$ & $-0,663$ & $-1,173$ & $-2,191$ & $-2,701$ & & $-1,224$ & \\
\hline Significance & 0,507 & 0,241 & 0,028 & 0,007 & & 0,221 & \\
\hline
\end{tabular}

Table 8. Resting and ND arm compared LDH enzyme statistical analysis values

\begin{tabular}{llllll}
\hline \multirow{2}{*}{ Variables } & $\begin{array}{l}\text { Ldh rest }- \\
\text { Ldh ND 0. } \mathbf{m}\end{array}$ & $\begin{array}{l}\text { Ldh rest }- \\
\text { Ldh ND 6. } \mathbf{h}\end{array}$ & $\begin{array}{l}\text { Ldh rest }- \\
\text { Ldh ND 24. } \mathbf{h}\end{array}$ & $\begin{array}{l}\text { Ldh rest }- \\
\text { Ldh ND 48. } \mathbf{h}\end{array}$ & $\begin{array}{l}\text { Ldh rest - } \\
\text { Ldh ND 72. } \mathbf{h}\end{array}$ \\
\hline Z & $-1,376$ & $-1,988$ & $-2,244$ & $-2,497$ & $-1,580$ \\
Significance & 0,169 & 0,047 & 0,025 & 0,013 & 0,114 \\
\hline
\end{tabular}

values were not a statistically significant difference $(\mathrm{p}>$ $0.05)$.

According to Table 7, LDH enzyme activities were analyzed by comparing the pre-exercise (resting) value with the D arm at the first minute, 6, 24, 48, and 72nd hours after the exercise. There was no statistically significant difference at the first minute, 6 and 72nd hours values ( $p>0,05)$. A statistically significant difference was found in the 24 and 48th-hour values $(\mathrm{p}<0.05)$.

According to Table 8, pre-exercise (resting) values were analyzed by comparing to ND LDH enzyme activities at the first minute, 6, 24, 48, and 72nd hours after the exercise. There was no statistically significant difference between at the first minute and 72nd hours values ( $p>0.05)$. A statistically significant difference was found in the 6,24 , and 48th-hour values $(\mathrm{p}<0.05)$.

\section{Discussion}

Statistically significant differences were found in ND arm CK, D arm CK, and D arm LDH enzymes. There was no statistically significant difference in ND arm LDH enzyme. These results prove that recovery in both arms occurred at 72nd hours. According to the values of CK and $\mathrm{LDH}$, at the first minutes, 24, 48 and 72nd hours, there was a statistically significant difference in D and ND arm values of both enzymes. As can be seen from these results, different reactions occurred in both enzymes in the D and ND arm.

There was no statistically significant difference between the D and ND arm CK enzymes at the first minute, 6, 24, and 72nd hours after the exercise. A statistically significant difference was found in the 48thhour values after exercise. According to these results, similar effects were observed in both arms after exercise, and at 48th hour the arms showed different reactions. In other words, muscle damage increased up to 48th hour reached its highest level at 48th hour, and recovery was achieved towards 72 nd hours.

There was no statistically significant difference between D and ND arm CK enzyme activities and D arm at the first minute, 6 and 72nd hours after the exercise. A statistically significant difference was found in the 24 and 48th-hour values. There was no statistically significant difference in ND arm values at the first minute, 48 and 72 nd hours, and a statistically significant difference was found in the 6th and 24th-hour values. Again, these results indicate that muscle damage reached the highest level at 24 and 48th hours, and returned to pre-exercise (resting) state around 72 th hour. The results indicated that CK enzyme values at the first minute, 6 and 72 nd hours of the $\mathrm{D}$ arm were similar to resting values, whereas 24 and 48th-hour values were different from resting values. In the ND arm, the values of the first minute, 48 and $72 \mathrm{nd}$ hours are similar to rest values, and the values of 6 and 
24th hours differ from rest values. Based on these results, recovery was observed in both arms, and recovery was faster in the ND arm compared to the D arm.

LDH enzyme activities of the D arm at the first minute, 6, 24, 48 and 72nd hours after the exercise were rested and no statistically significant difference was found in the first minute, 6, 72th hours. A statistically significant difference was found in the 24 and 48th-hour values. There was no statistically significant difference in ND arm values between rest and first minute and 72nd hours. A statistically significant difference was found in the values of 6,24, and 48th hours. According to these results, it was seen that the LDH enzyme reached the highest level in both arms at 24 and 48th hours and recovery occurred in similar periods.

The results of the study conducted by Hazar et al., [30] strength training after the study of the relationship between muscle pain and muscle damage with their study, Jubeau et al., [31] voluntary and stimulating contractions of muscle strength, growth hormone $(\mathrm{GH})$, blood lactate and muscle damage is aimed to compare changes with voluntary and stimulated leg press exercise serum growth hormone concentration, blood lactate, isometric maximal voluntary contraction strength (MVC), serum creatine kinase (CK) activity and muscle pain were similar in terms of recovery time.

In addition, in terms of recovery time of creatine kinase (CK) enzyme results of the study, Nosaka and Clarkson, [32] maximal isometric power, elbow angle, muscle pain and cretin kinase levels are aimed to determine the eccentric phase of elbow flexion movement, Jamurtas et al., [33] of a similar intensity of eccentric muscle injury in the leg and arm after the exercise aimed to compare submaximal workload eccentric knee extension and elbow flexion movement they have done and Bruunsgaard et al., [34] increased cytokine level after exercise and muscle damage is similar to the work done to determine the intended muscle damage.

\section{Conclusions}

As a result, muscle damage after supramaximal eccentric exercise increased at 24 and 48th hours and returned to baseline at 72 nd hours. A statistically significant difference in the 48 and 72 nd-hour values is an indication of this situation. Although similar results were observed, the non-dominant arm recovered faster than the dominant arm. CK enzyme, the right arm values, the left arm values are a statistically significant difference is an indicator of this situation. This can be attributed to the lower performance of the subjects with non-dominant arms.

The results of this study will help athletes, coaches, or researchers to know what changes are happening to the human body after an exercise involving eccentric contractions with the supramaximal workload. Also, this study will help to prepare the training units, and recovery periods will be more comfortable to determine when the recovery time is fully known.

Suggestions for the future studies

- In addition to this study, different enzyme activities, which are markers of muscle damage, can be examined.

- Muscle damage can be examined by taking a muscle sample (biopsy).

- Muscle damage and changes in recovery time can be examined by taking blood samples at different times.

\section{Suggestions for researchers}

- Based on the results of this study, researchers may investigate the rate of muscle damage removal by taking some dietary supplements that are known to help recovery during rest.

- Investigate contraction types and interactions with different contraction exercises for different extremities (dominant or non-dominant).

\section{Conflict of interests}

The authors declare that there is no conflict of interests.

\section{References}

1. Holmann W. Sport-Medicine. Berlin: Springer Verlag, 1972.

2. Nett T. Leichtathletiches muskel training [Track and field muscle training]. Berlin: Verlag Bartels und Wernitz K. G., 1970. (In German)

3. Şen İ. Effect of carbohydrate-protein (Cho-p) supplement on attenuation of muscle damage induced by eccentric exercise in Turkish ski racers. Turkish J Phys Med Rehab, 2011;57:1418.

4. Erdoğan M. Farklı ısı koşullarında uygulanan maksimal aerobikyüklenmenin kas hasart ve performans üzerine etkileri [The effect of the different heat conditions after maximal endurance exercise on muscle damage and performance]. Ankara: Gazi University Press; 2009. (In Turkish)

5. Hazar S. Farklı türdeki kuvvet antrenmanlarının iskelet ve kalp kasi enzim aktivitelerine akut etkisi [Accute effect of various strength training on skeletal muscle enzyme activities and on myocard enzyme activities]. Ankara: Gazi University Press; 2004. (In Turkish)
6. Akyüz M. Müsabaka süresince erkek futbolcularda oluşan kas hasarl [The muscle damage occured on young male fotball players during match]. Ankara: Gazi University Press; 2007. (In Turkish)

7. Christopher T, Daley W. In: Bull R, Charles O R, William O R. Bull's handbook of sports injuries. $2^{\text {nd }}$ ed., New York: Mc Graw Hill Publishing Company; 2004.

8. Ross M. Delayed-onset muscle soreness work out now, pay later? The physician and sports medicine, 1999; 27 (1): 9- 13. https://doi.org/10.3810/psm.1999.01.625

9. Murray RK, Gramer DK, Mayes PA, Rodwel VW. Harper' in biyokimyası [Harper's biochemistry]. 24th ed. İstnabul: Barış Kitabevi; 1998. (In Turkish)

10.Vasilis M. Reference intervals for serum creatine kinase in athletes. Br J Sports Med, 2007; 41: 674- 678. https://doi.org/10.1136/bjsm.2006.034041

11.Harbili S, Gencer E, Ersöz G, Demirel H A. Orta şiddetli ekzentrik egzersiz diğer hasar belirteçlerini etkilemeksizin plazma kreatin kinaz düzeyini arttırır [Moderate intensity 
eccentric exercise results in increases in plasma ck level without effecting any other damage indicators]. Selçuk Üniversitesi Bed Ĕgt ve Sp Bil Der, 2008; 10 (1): 21-31. (In Turkish)

12.Güçlü G. Yüzme ve koşu egzersizinin slçan kas lifi tipleri üzerine etkisi [The effect of swimming and treadmill exercises on muscle fiber type of rat]. Kayseri: Erciyes University Press; 2008. (In Turkish)

13.Smith L L, Miles M P. Exercise-induced muscle injury and inflammation In.: William E, Garret $\mathrm{J}$ R, Kirkendall D T. Exercise and sport science. Philadelphia: Lippincott Williams and Wilkins, 2000. P. 401-411.

14.Walsh B, Tonkonogi M, Malm C, Ekblom B, Sahlin $\mathrm{K}$. Effect of eccentric exercise on muscle oxidative metabolism in humans. Medicine and science in sports and exercise, 2001; 33 (3): 436- 441. https://doi.org/10.1097/00005768-200103000-00016

15.Archana P, Lal AK, Negi KS. Serum creatine kinase activity in thyroid disorders. $J$ K Sci, 2007; 9 (1): 25-26.

16.Günay M, Cicioğlu İ. Spor fizyolojisi [Sport physiology]. Ankara: Gazi Kitapevi; 2001. (In Turkish)

17.Kaplan LA, Pesce AJ. Clinical chemistry: Theory, analysis, and correlation. $3^{\text {rd }}$ ed., St Louis: Mosby Publishing; 1996.

18.Schumann G, Klauke R. New IFCC reference procedures for the determination of catalytic activity concentrations of the five enzymes in serum: Preliminary upper reference limits obtained in hospitalized subjects. Clin Chem Acta, 2003; 327:69- 79. https://doi.org/10.1016/S0009-8981(02)00341-8

19.Vural S, Çetin E, Tuzlacı U. Klinik teşhiste laboratuar [Laboratory in clinical diagnosis]. İstanbul: Uycan Basim Sanayi; 1986. (In Turkish)

20.Bernard J H. Clinical diagnosis and management by laboratory methods. $20^{\text {th }}$ ed., Philadelphia: W. B. Saunders Company; 2001.

21.Wallach J. Interpretation of diagnostic tests. $7^{\text {th }}$ ed., Philadelphia: Lippincott Williams and Wilkins; 2000.

22.Harbili S. Egzersize bağlı kas hasarı. [Muscle injury due to exercise] Atletizm bilim ve teknoloji dergisi, 2004; 55: 13-18. (In Turkish)

23.Kasper CE, Talbot LA, Gaines JM. Skeletal muscle damage and recovery. American association of critical nurse clinical, 2002; 12 (2): 237- 247. https://doi.org/10.1097/00044067-200205000-00009

24.Clarkson PM, Nosaka K, Braun B. Muscle function after exercise-induced muscle damage and rapid adaptation. Medicine and science in sports and exercise, 1992; 24 (5): 512- 520. https://doi.org/10.1249/00005768-199205000-00004

25.Ebbeling CB, Clarkson PM. Exercise-induced muscle damage and adaptation. Sports Med, 1989; 7 (4): 207- 234. https://doi.org/10.2165/00007256-198907040-00001

26.Nosaka K, Clarkson PM, Mc Guiggin ME, Byrne JM. Time course of muscle adaptation after high force eccentric exercise. Eur $J$ Appl Physiol and Occupational Physiol, 1991; 63 (1): 70- 76. https://doi.org/10.1007/BF00760804

27.Allen DG. Eccentric muscle damage: Mechanisms of early education of force. Acta physiologica seandinamics, 2001; $171 \quad$ (3): $311-319$. https://doi.org/10.1046/j.1365-201x.2001.00833.x

28.Clancy SP, Clarkson PM. Immobilization during recovery from eccentric exercise-induced muscle damage. Medicine and science in sports and exercise, 1990; 22: 37. https://doi.org/10.1249/00005768-199004000-00220

29.Lehto M, Duance VC, Restall D. Collagen and fibronectin in a healing skeletal muscle injury. An immunohistological study of the effects of physical activity on the repair of injured gastrocnemius muscle in the rat. J. Bone and Joint Surgery British Volume, 1985; 67-B (5): 820- 828. https://doi.org/10.1302/0301-620X.67B5.3902851

30.Hazar S, Erol E, Gökdemir K. Kuvvet antrenmanı sonras1 oluşan kas ağrısının kas hasarıyla ilişkisi [The relationship between the muscle damage and muscle sorenes after strength training]. Gazi beden eğitimi ve spor bilimleri dergisi, 2006; 11 (3): 49-58. (In Turkish)

31.Jubeau M, Sartorio A, Marinone PG, Agosti F, Van Hoecke J, Nosaka K, Maffiuletti NA. Sex differences in steroidogenesis in skeletal muscle following a single bout of exercise in rats. J Appl Physiol, 2008; 104 (1): 75- 81. https://doi.org/10.1152/japplphysiol.00335.2007

32.Nosaka K, Clarkson P M. Muscle damage following repeated bouts of high force eccentric exercise. Medicine and science in sports and exercise, 1995; 27 (9):1263- 1269. https://doi.org/10.1249/00005768-199509000-00005

33.Jamurtas AZ, Theocharis V, Tofas T, Tsiokanos A, Yfanti C, Paschalis V, Koutedakis Y, Nosaka K. Comparison between leg and arm eccentric exercises of the same relative intensity on indices of muscle damage. Eur J Appl Physiol, 2005; 95 (2): 179- 185. https://doi.org/10.1007/s00421-005-1345-0

34.Bruunsgaard H, Galbo H, Halkjaer-Kristensen J, Johansen TL, MacLean DA, Pedersen BK. Exercise-induced increase in serum interleukin-6 in humans is related to muscle damage. Journal of physiology, 1997; 499 (3): 833- 841. https://doi.org/10.1113/jphysiol.1997.sp021972 


\section{Information about the authors:}

Yapıcı A.; (Corresponding author); http://orcid.org/0000-0002-9293-5772; ademyapici@mku.edu.tr; School of Physical Education and Sports, Hatay Mustafa Kemal University; Antakya, Hatay, Turkey.

Yalçın H.B.; http://orcid.org/0000-0001-5038-0759; yalcin_h@ibu.edu.tr; Faculty of Physical Education and Sports, Bolu Abant İzzet Baysal University; 14030 - Merkez / Bolu. Turkey.

Cite this article as:

Yapıcı A, Yalçın HB. Investigation of the effect of supramaximal eccentric contractions on muscle damage and recovery between the dominant and non-dominant arm. Pedagogics, psychology, medical-biological problems of physical training and sports, 2019;23(6):306-312.

https://doi.org/10.15561/18189172.2019.0605

This is an Open Access article distributed under the terms of the Creative Commons Attribution License, which permits unrestricted use, distribution, and reproduction in any medium, provided the original work is properly cited (http://creativecommons.org/licenses/by/4.0/deed.en).

Received: 05.08.2019

Accepted: 04.09.2019; Published: 30.09.2019 